Article

\title{
Zwitter-Ionic Polymer Applied as Electron Transportation Layer for Improving the Performance of Polymer Solar Cells
}

\author{
Qiaoyun Chen ${ }^{(D)}$, Zhendong Li ${ }^{(1)}$, Bin Dong, Yi Zhou * and Bo Song * \\ College of Chemistry, Chemical Engineering and Materials Science, Soochow University, Suzhou 215123, China; \\ chenqiaoyun1995@163.com (Q.C.); lizhendong@zoho.com (Z.L.); bdong@suda.edu.cn (B.D.) \\ * Correspondence: yizhou@suda.edu.cn (Y.Z.); songbo@suda.edu.cn (B.S.); \\ Tel.: +86-(0)512-65882653; +86-(0)512-65882507
}

Received: 2 October 2017; Accepted: 27 October 2017; Published: 1 November 2017

\begin{abstract}
A zwitter-ionic polymer poly (sulfobetaine methacrylate) (denoted by PSBMA) was employed as an electron transportation layer (ETL) in polymer solar cells (PSCs) based on poly(3-hexylthiophene) (P3HT):[6,6]-phenyl- $\mathrm{C}_{61}$-butyric acid methyl ester $\left(\mathrm{PC}_{61} \mathrm{BM}\right)$. PSBMA is highly soluble in trifluoroethanol, showing an orthogonal solubility to the solvent of the active layer in the preparation of multilayered PSCs. Upon introduction of PSBMA, the short circuit current and as a consequence the power conversion efficiency of the corresponding PSCs are dramatically improved, which can be because of the relatively high polarity of PSBMA compared with the other ETLs. This study demonstrated that zwitter-ionic polymer should be a competitive potential candidate of ETLs in PSCs.
\end{abstract}

Keywords: PSBMA; betaine; zwitter-ionic polymer; ETL

\section{Introduction}

Polymer solar cells (PSCs) with a bulk heterojunction (BHJ) structure have attracted extensive research attention owing to advantages, such as light-weight, low cost, flexibility, and large-area fabrication [1,2]. Recently, the power conversion efficiencies (PCEs) of single-junction PSCs have reached 13\% [3-6], owing to the molecular design of photoactive materials [3,7-12], interface engineering [13-16], and improvement of device configurations. Although the design of new photoactive materials plays a key role in this concern, the steps for exploration of high efficient interfacial materials that can facilitate the charge collection and transportation have never ceased. For PSCs, the interfacial materials are demanded to have good wetting processing ability and solvent orthogonal property with the solvent used to dissolve the photoactive materials. In this regard, compared with conventional inorganic electron transportation layers (ETLs), such as $\mathrm{Ca}$ and $\mathrm{LiF}$ etc. [17], the water-/alcohol-soluble polymers (polyfluorene derivatives [18,19], polyethyleneimine [20-23], ethoxylated polyethyleneimine [24,25] etc.), and small organic molecules [3,26-28] show their priority in fabrication of low-cost and large-area PSCs [29]. The inorganic metal oxides (e.g., $\mathrm{ZnO}$ [30-33], $\mathrm{TiO}_{\mathrm{x}}$ [34-37], etc.), metal salts (CsF [38], $\mathrm{Cs}_{2} \mathrm{CO}_{3}[39]$, etc.), and self-assembled monolayers are successfully applied to improve the performance of PSCs. However, most of these inorganic ETLs showed poor interfacial contact with organic photoactive layer [40], which may hinder the effective charge extraction. In addition to the above-mentioned aspects, for organic interfacial materials, the suitable dipole moment is also an important factor that may affect the work function of the electrodes, and thus influence the resulting performance of the solar cell devices. 
To meet all the aforementioned properties, organic interfacial materials with functionalities, such as phosphonate [41], ethylene oxide [42,43], amino or ammonium [44,45], etc. have been widely studied as ETLs. It has been proven that the introduction of these materials can indeed lower the work function of the adjacent electrode, and thus lead to the improvement of the corresponding solar cell devices. For this purpose, zwitter-ionic polymers that contain approximately twice as many polar groups compared with the typical ionic molecules, can possibly give higher surface dipoles, and thus be favorable for the electron transportation [26,46-48].

Herein, a solution-processable, electronically neutral zwitter-ionic polymer poly (sulfobetaine methacrylate) (denoted by PSBMA) was employed as the ETL in PSCs. Since P3HT was widely studied as a model material in PSCs, herein we also employed P3HT:PC ${ }_{61} \mathrm{BM}$ as the active layer. It was anticipated that the sulfobetaine moiety on the side chain should provide a strong permanent moment, which can reduce the work function (WF) of cathode electrode and then alleviate the interfacial energy barriers. The results indicate that PSBMA provides orthogonal solubility in the fabrication of multi-layered solar cells. Under optimized conditions, a PCE of 3.67\% was achieved when using PSBMA as ETL, presenting a notable improvement compared with that $(3.49 \%)$ of the devices without PSBMA.

\section{Materials and Methods}

\subsection{Materials}

[2-(methacryloyloxy)ethyl]dimethyl-(3-sulfopropyl)ammonium hydroxide, 4,4-azobis(4cyanovaleric acid) (ACVA), and 4-cyano-4-(thiobenzoylthio) pentanoic acid were purchased from Alfa Aesar (China) Chemicals Co., Ltd. (Shanghai, China). 2,2,2-trifluoroethanol (TFE) was purchased from J\&K Technology Co., Ltd. (Beijing, China). The PSBMA was synthesized according to the reported literature [49-51]. The PEDOT:PSS solution was purchased from Heraeus Precious Metals GMBH \& Co. KG (Leverkusen, Germany). P3HT and $\mathrm{PC}_{61} \mathrm{BM}$ were purchased from 1-Material Co., Ltd. (Dorval, QC, Canada) and Solarmer Materials Inc. (Beijing, China), respectively. Al was acquired from Zhong Nuo Advanced Material Technology Co., Ltd. (Beijing, China).

\subsection{Fabrication of Devices}

The PSCs were fabricated with a configuration of ITO/PEDOT:PSS/P3HT:PC 61 BM/ETL/Al. The ITO-coated glass ( $10 \Omega$ per square) was cleaned by sequential ultrasonification in water containing the dish washing liquid, deionized water, acetone, ethanol and isopropanol twice each solvent and 15 min each time, and then treated with ultraviolet-ozone by a UVO cleaner (Jelight Company, Inc., 2 Mason, Irvine, CA, USA) for $20 \mathrm{~min}$. A PEDOT:PSS layer $(\sim 40 \mathrm{~nm})$ was spin-coated onto the cleaned ITO substrates at $5000 \mathrm{rpm}$ for $40 \mathrm{~s}$, and the substrates were annealed at $150{ }^{\circ} \mathrm{C}$ for $15 \mathrm{~min}$ in air. Then, an $o$-chlorobenzene solution of P3HT:PC ${ }_{61} \mathrm{BM}$ blend $(1: 1 w / w$, total concentration of $40 \mathrm{mg} / \mathrm{mL}$ ) was spin-coated onto the PEDOT:PSS at $900 \mathrm{rpm}$ for $30 \mathrm{~s}$. Under the above conditions, the thickness of the P3HT:PC ${ }_{61} \mathrm{BM}$ blend were controlled to $\sim 230 \mathrm{~nm}$. The TFE solution of PSBMA with a concentration of $0.25,0.5$, and $0.75 \mathrm{mg} / \mathrm{mL}$ was spin-coated onto the active layer at a speed of $4500 \mathrm{rpm}$ for $45 \mathrm{~s}$, respectively. The Ca layer $(20 \mathrm{~nm})$ and the $\mathrm{Al}$ electrode $(80 \mathrm{~nm})$ was thermally evaporated atop of PSBMA with a shadow mask to define the effective area of $0.04 \mathrm{~cm}^{2}$ under a pressure of $2 \times 10^{-4} \mathrm{~Pa}$.

\subsection{Measurement and Characterization}

Nuclear Magnetic Resonance (NMR) spectrum was measured on Bruker AV-500 MHz spectrometer (Bruker, Santa Barbara, CA, USA). Gel permeation chromatography measurement (GPC) was carried out in TFE with $0.02 \mathrm{~mol} / \mathrm{L}$ sodium trifluoroacetate at $40{ }^{\circ} \mathrm{C}$ using an Agilent 1200 system equipped with an isocratic pump operated at $1 \mathrm{~mL} / \mathrm{min}$, a degasser, an autosampler, one $50 \mathrm{~mm} \times 8 \mathrm{~mm}$ PSS PFG guard column (Polymer Standards Service), three $300 \mathrm{~mm} \times 7.5 \mathrm{~mm}$ PSS PFG analytical linear M columns with particle size of $7 \mu \mathrm{m}$ (Polymer Standards Service) 
calibrated against poly(methyl methacrylate) (PMMA) standards, and an Agilent 1200 refractive index detector (Agilent, Anaheim, CA, USA). Electrochemical cyclic voltammetry (CV) was performed on a Zahner Ennium IM6 Electrochemical Workstation with a glassy carbon disk, Pt wire, and $\mathrm{Ag} / \mathrm{Ag}^{+}$electrode as the working electrode, counter electrode, and reference electrode, respectively. The tetra- $n$-butylammoniumhexafluoro-phosphate $\left(n-\mathrm{Bu}_{4} \mathrm{NPF}_{6}, 0.1 \mathrm{~mol} / \mathrm{L}\right.$ in acetonitrile) as the supporting electrolyte. The ferrocene/ferrocenium $\left(\mathrm{Fc} / \mathrm{Fc}^{+}\right)$was used as an internal standard, which was assigned an absolute energy of $-4.8 \mathrm{eV}$ vs. vacuum level. The morphologies of active layer and ETL surfaces were characterized by Atomic Force Microscope (AFM) on a Multimode 8 microscope (Bruker, Santa Barbara, CA, USA) in air using ScanAsyst-Air probes. The force constant was $0.4 \mathrm{~N} / \mathrm{m}$. The set point was $0.08 \mathrm{~V}$. The scan rate was $0.977 \mathrm{~Hz}$. The thicknesses of the films were recorded with a spectroscopic ellipsometer (M-2000 V, J.A. Woollam Co., Lincoln, NE, USA). The J-V curves were measured in a glovebox with an SS-F5-3A solar simulator and a Keithley 2400 source meter unit under standard Air Mass 1.5 Global (AM $1.5 \mathrm{G})\left(100 \mathrm{~mW} \mathrm{~cm}{ }^{-2}\right)$ illumination calibrated by a standard Si solar cell (SRC-2020, Enli Technology Co., Ltd., Taiwan) and when testing there was no mask. The external quantum efficiency (EQE) data were recorded on a QE-R3011 (Enli Technology Co., Ltd., Taiwan), where the light intensity was calibrated by a standard Si solar cell (RC-S10-A, Enli Technology Co., Ltd., Taiwan) certified by Taiwan Accreditation Foundation (TAF).

\section{Results and Discussion}

\subsection{Synthsis of the PSBMA}

The synthetic route of the target compound PSBMA is shown in Scheme 1, which mainly referred to the work of Zachariah et al. [49-51], using the reversible addition-fragmentation chain transfer (RAFT) polymerization. Herein, methacryloxyethyl sulfobetaine, 4-cyano-4-(thiobenzoylthio) pentanoic acid, ACVA and TFE were used as the monomer, chain transfer agent, initiator, and solvent, respectively. The product is a fine pink powder, showing a good solubility in TFE and water but a poor solubility in methanol and ethanol. Because of its unique solubility, TFE can be used as a solvent to avoid damaging the active layer during the spin-coating process. As shown in Figure 1, the resulting product was confirmed by ${ }^{1} \mathrm{H}-\mathrm{NMR}$ spectra and GPC. The ${ }^{1} \mathrm{H}-\mathrm{NMR}$ spectra shows the resonances for the $-\mathrm{COOCH}_{2}{ }^{-}$group at $\delta 4.56 \mathrm{ppm}$ (labeled as protons a), for the $-\mathrm{CH}_{2} \mathrm{~N}^{+}\left(\mathrm{CH}_{3}\right)_{2} \mathrm{CH}_{2}{ }^{-}$group at $\delta 3.86$, $3.28,3.66 \mathrm{ppm}$ (labeled as protons $\mathrm{b}, \mathrm{d}$ and c, respectively), for $-\mathrm{CH}_{2}{ }^{-}$group at $\delta 2.33 \mathrm{ppm}$ (labeled as protons $\mathrm{f}$ ), for $-\mathrm{CH}_{2} \mathrm{SO}_{3}{ }^{-}$group at $\delta 3.02 \mathrm{ppm}$ (labeled as protons e) and for the $-\mathrm{CH}_{2} \mathrm{CCH}_{3}{ }^{-}$group at $\delta 1.04 \sim 1.21 \mathrm{ppm}$ (labeled as protons $\mathrm{g}$ and $\mathrm{h}$, respectively). As listed above, the chemical shifts correspond to the protons in different chemical environment of the target molecule, and the most of the peak became broad and the coupling information were not differentiable. These results indicate the compound we have synthesized should be the polymer we designed. The ${ }^{1} \mathrm{H}-\mathrm{NMR}$ data are also in accordance with the literature [52], further confirming the chemical structure of the target polymer. The result of GPC showed that the number average molecular weight $\left(M_{\mathrm{n}}\right)$ is $11.4 \mathrm{kDa}$, and weight average molecular weight $\left(M_{\mathrm{W}}\right)$ is $13.8 \mathrm{kDa}$. The polydispersity index (PDI) is 1.2, implying that the product has a relatively narrow molecular weight distribution.

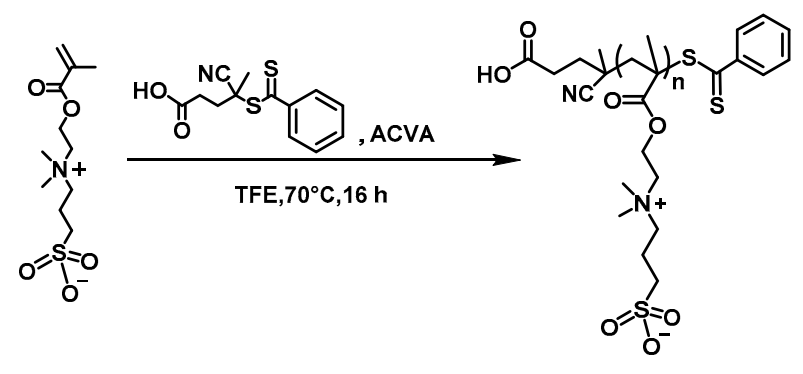

Scheme 1. Synthetic route of poly (sulfobetaine methacrylate) (PSBMA). 

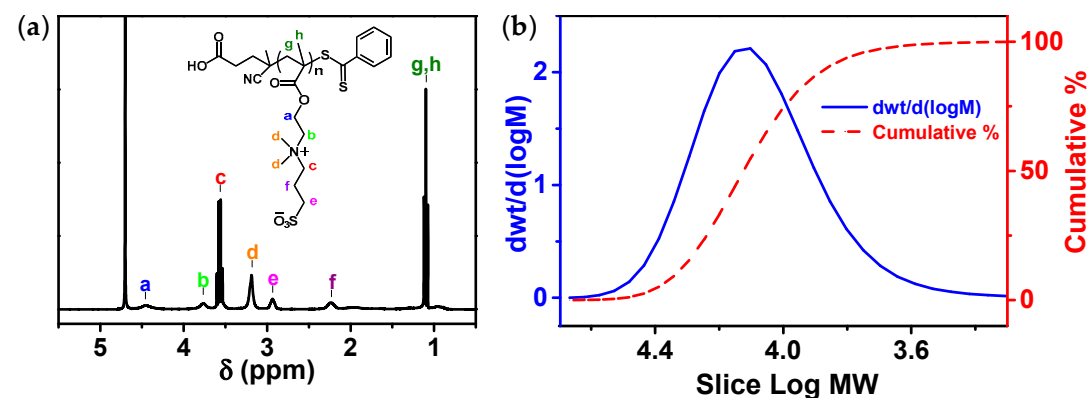

Figure 1. (a) ${ }^{1} \mathrm{H}-\mathrm{NMR}$ spectrum and (b) Gel permeation chromatography measurement (GPC) curves of PSBMA, where $w t$ is weight, $M_{\mathrm{W}}$ is molecular weight.

\subsection{The Thickness Control of the PSBMA Films}

The thicknesses of spin-coated films mainly depend on the solution concentration, spin speed, and time. In order to obtain a parallel comparison, herein the spin speed and time were fixed to $4500 \mathrm{rpm}$ and $45 \mathrm{~s}$, respectively. The concentration of the PSBMA solution was taken as variables to investigate the thickness change, and the silicon wafers were employed as substrates. After being prepared on silicon wafers, the PSBMA films were annealed at $80^{\circ} \mathrm{C}$ for $15 \mathrm{~min}$, and then the thicknesses of them was determined on an ellipsometer. As shown in Figure 2, the thicknesses of the films increased with the concentration of the corresponding solutions. Through varying the concentrations from $0.25,0.5$, to $0.75 \mathrm{mg} / \mathrm{mL}$, the film thicknesses of approximately $4.1,5.6$, and $7.0 \mathrm{~nm}$ were obtained, respectively.

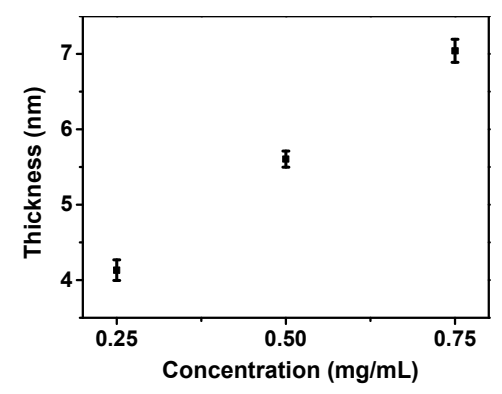

Figure 2. The thickness versus the corresponding concentration of PSBMA. The films were prepared by spin-coating at $4500 \mathrm{rpm}$ for $45 \mathrm{~s}$.

\subsection{Morphologies of P3HT:PC ${ }_{61} B M$ and PSBMA@P3HT:PC ${ }_{61} B M$}

The surface morphology and aggregation state of the interlayer have great effect on the device performance and an active layer with an inner film morphology fulfills the requirements of high-performance solar cells $[53,54]$. In addition, two more specific variables drive us to investigate the morphology of the PSBMA. (1) TFE is not an often-used solvent for preparation of thin films on P3HT:PC ${ }_{61} \mathrm{BM}$ active layer; (2) the highly polar PSBMA due to the ionic feature might be a problem on spreading at the apolar surface of P3HT:PC ${ }_{61} \mathrm{BM}$. Figure 3 shows the AFM height images of the P3HT:PC ${ }_{61} \mathrm{BM}$ and PSBMA@P3HT:PC ${ }_{61} \mathrm{BM}$. In the previous publications $[55,56]$, the effect of solvent on the morphology of P3HT:PCBM blend films was investigated by different methods, such as AFM and grazing-incidence wide-angle $X$-ray scattering. The surface morphology measured by AFM can also reflect the inner structure of the films. Herein, the images clearly show the phase separation of the active layer. After being covered by $5.6 \mathrm{~nm}$ thick PSBMA film, the surface morphology did not change too much, and the phase separation of the active layer can still be observable. Through these images, we can conclude that PSBMA can spread uniformly on the P3HT:PC ${ }_{61} \mathrm{BM}$ blend film, and the TFE solvent has very little influence on the morphology of the active layer. 


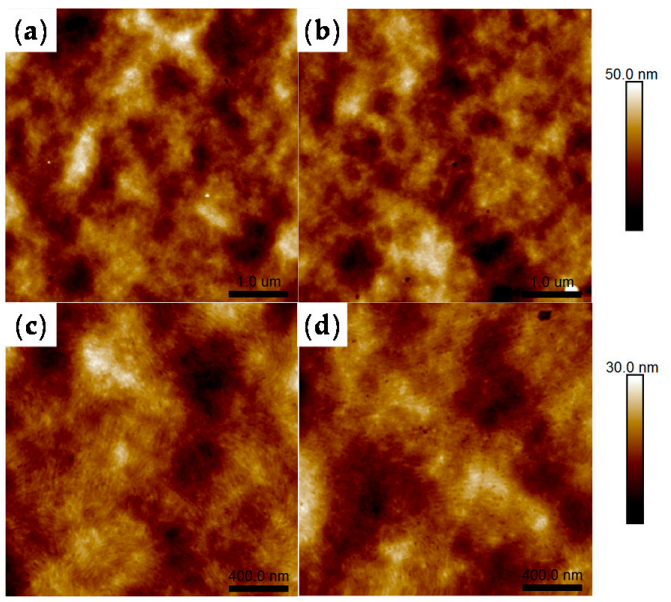

Figure 3. Atomic Force Microscope (AFM) height images of (a,c) P3HT:PC ${ }_{61} \mathrm{BM}$ and $(\mathbf{b}, \mathbf{d})$ PSBMA@P3HT:PC 61 BM. Here the thickness of PSBMA was $5.6 \mathrm{~nm}$. The scanning areas of $(\mathbf{a}, \mathbf{b})$ and $(\mathbf{c}, \mathbf{d})$ are $5 \times 5 \mu \mathrm{m}^{2}$ and $2 \times 2 \mu \mathrm{m}^{2}$, respectively.

\subsection{Electrochemical Properties}

In this study, we adopted the conventional solar cell structure (i.e., using ITO as anode (as shown in Figure 4a), and PSBMA was inserted between the active layer and the cathode) to investigate the charge transportation ability of PSBMA. The devices without PSBMA layer were also fabricated in parallel conditions and adopted as control. One of the key issues of interfacial layers is the energy level alignment. Herein, the energy levels of PSBMA were determined by cyclic voltammetry (CV) as shown in Figure $4 \mathrm{~b}$, in which the small image showed the $\mathrm{CV}$ curve of $\mathrm{Fc} / \mathrm{Fc}^{+}$under the same experimental conditions. From the $\mathrm{CV}$ curve, the highest occupied molecular orbital (HOMO) level ( $\left.E_{\mathrm{HOMO}}\right)$ and the lowest unoccupied molecular orbital (LUMO) level ( $E_{\text {LUMO }}$ ) of PSBMA were estimated to be -6.29 and $-3.45 \mathrm{eV}$, respectively. The energy levels of each component in the PSCs are illustrated in Figure 4c. It is clearly shown that PSBMA should be suitable to be an ETL between the active layer and cathode. In addition to the energy level alignment, the high polarity of PSBMA was also expected to improve the transportation of electron and reduce the interfacial charge recombination. This assertion is in accordance with the previous publications $[26,57,58]$. For example, the highly polar $-\mathrm{SO}_{3}{ }^{-}$and amine are both responsible to the transportation of charge carriers around the electrodes [26].

(a)

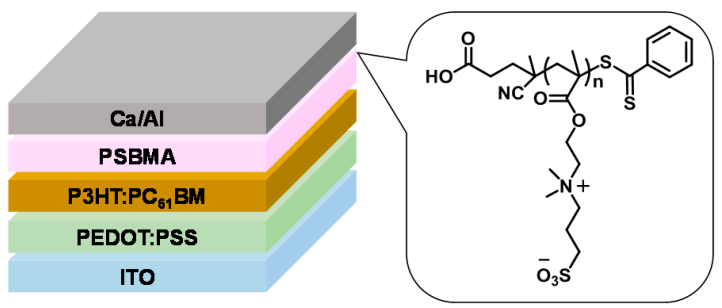

(b)
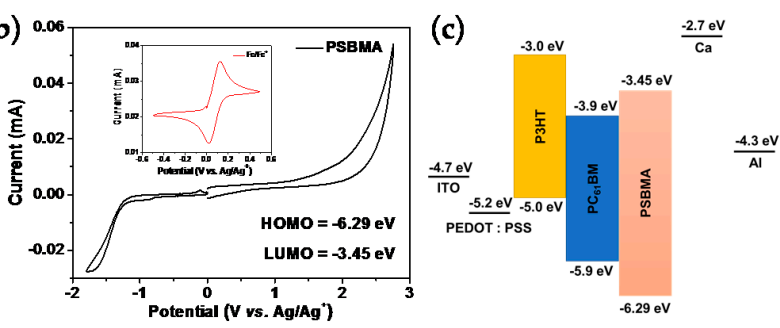

Figure 4. (a) Schematic illustration of the device structure of PSCs adopted in this study. (b) The cyclic voltammetry (CV) curve of PSBMA. (c) Energy level diagram of each component used in the PSCs. 


\subsection{Photovoltaic Properties}

To investigate the effect of the PSBMA interlayer on the performance of the devices, the photovoltaic properties of the corresponding PSCs was investigated under simulated AM $1.5 \mathrm{G}$ illumination with an intensity of $100 \mathrm{~mW} / \mathrm{cm}^{2}$. The current density-voltage $(J-V)$ curve and the corresponding external quantum efficiency (EQE) curve of the PSC devices are shown in Figure 5. The detailed performance parameters of the corresponding devices are summarized in Table 1. The control device reached a PCE of $3.49 \%$, with the short-circuit current density $\left(J_{\mathrm{sc}}\right)$ of $8.21 \mathrm{~mA} / \mathrm{cm}^{2}$, an open-circuit voltage $\left(V_{\mathrm{oc}}\right)$ of $0.64 \mathrm{~V}$ and a fill factor $(\mathrm{FF})$ of $65.9 \%$. Upon insertion of PSBMA interlayer, $J_{\mathrm{sc}}$ of the device was clearly improved. When the thickness of PSBMA layer was $5.6 \mathrm{~nm}$, a highest PCE was achieved up to $3.67 \%$ with a $J_{\mathrm{sc}}$ of $9.32 \mathrm{~mA} / \mathrm{cm}^{2}$, a $V_{\mathrm{oc}}$ of $0.63 \mathrm{~V}$, and a FF of $62.5 \%$. The increase of $J_{\mathrm{sc}}$ can also be confirmed by the integrated current density $\left(J_{\text {int }}\right)$ obtained from the corresponding EQE curves. These two groups of values are also comparable, indicating that the $J_{\mathrm{sc}} \mathrm{S}$ from $J-V$ curves should be reliable.
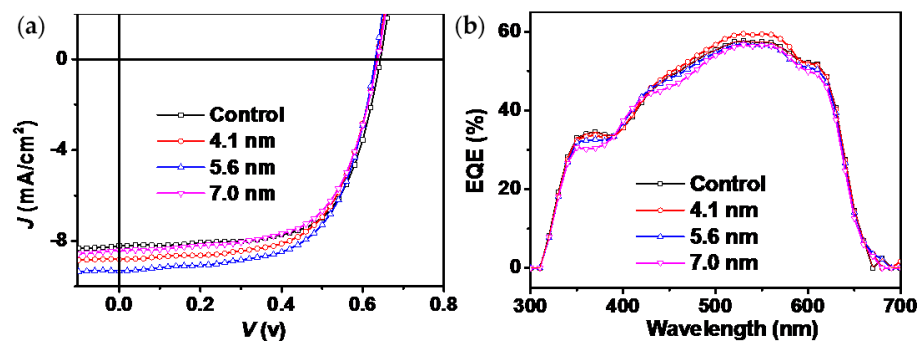

Figure 5. (a) Density-voltage $(J-V)$ and (b) external quantum efficiency (EQE) curves of PSCs without and with PSBMA ETLs. The thickness of PSBMA varied as 4.1, 5.6, and $7.0 \mathrm{~nm}$.

Table 1. Detailed parameters of PSC devices with/without PSBMA ETLs.

\begin{tabular}{ccccc}
\hline ETL & Voc $(\mathbf{V})$ & J sc $\left(\mathbf{m A} / \mathbf{c m}^{\mathbf{2}}\right)$ & FF (\%) & PCE (\%) \\
\hline $\mathrm{Ca}$ & $0.64^{\mathrm{a}}(0.63 \pm 0.01)^{\mathrm{b}}$ & $8.21(8.04 \pm 0.17)$ & $65.9(64.8 \pm 0.7)$ & $3.49(3.31 \pm 0.12)$ \\
$4.1 \mathrm{~nm}$ & $0.64(0.63 \pm 0.01)$ & $8.81(8.52 \pm 0.20)$ & $64.7(63.4 \pm 1.0)$ & $3.51(3.43 \pm 0.05)$ \\
$5.6 \mathrm{~nm}$ & $0.63(0.63 \pm 0.00)$ & $9.32(8.99 \pm 0.19)$ & $62.5(60.7 \pm 1.5)$ & $3.67(3.44 \pm 0.15)$ \\
$7.0 \mathrm{~nm}$ & $0.64(0.63 \pm 0.01)$ & $8.43(8.29 \pm 0.01)$ & $64.1(62.9 \pm 0.7)$ & $3.37(3.29 \pm 0.05)$ \\
\hline \multicolumn{5}{c}{ a Optimal device; ${ }^{\mathrm{b}}$ Average value obtained from six devices. }
\end{tabular}

\section{Conclusions}

In this study, the classical P3HT:PCBM-based PSCs was employed as a model system to demonstrate the possibility of using zwitter-ionic polymer as ETLs in PSCs. Herein, a betaine-based polymer (i.e., PSBMA) was synthesized and used as a zwitter-ion material. Owning to the high polarity, PSBMA showed a clear improvement effect on the current density of the resulting PSC devices, and hence the total PCE was also enhanced. Although PSBMA has high polarity nature, the film can spread well on the apolar P3HT:PC ${ }_{61} \mathrm{BM}$ surface, and the rarely used TFE solvent have little damage on the surface morphology of P3HT: $\mathrm{PC}_{61} \mathrm{BM}$. This work may offer a new strategy to design ETL materials for highly efficient PSCs.

Acknowledgments: This work was supported by the National Natural Science Foundation of China (51673138 and 91333204), Innovative Entrepreneurship Training Program for College Students of Soochow University (2015xj016), a Priority Academic Program Development of Jiangsu Higher Education Institutions, State and Local Joint Engineering Laboratory for Novel Functional Polymeric Materials.

Author Contributions: Qiaoyun Chen and Zhendong Li performed the experiments, collected and processed the experimental data. Bin Dong, Yi Zhou and Bo Song designed this research work and directed and supervised the research. Bo Song, Qiaoyun Chen and Zhendong Li did the data analysis and wrote the paper.

Conflicts of Interest: The authors declare no conflict of interest. 


\section{References}

1. He, Z.; Xiao, B.; Liu, F.; Wu, H.; Yang, Y.; Xiao, S.; Wang, C.; Russell, T.P.; Cao, Y. Single-junction polymer solar cells with high efficiency and photovoltage. Nat. Photonics 2015, 9, 174-179. [CrossRef]

2. Krebs, F.C. Fabrication and processing of polymer solar cells: A review of printing and coating techniques. Sol. Energy Mater. Sol. Cells 2009, 93, 394-412. [CrossRef]

3. Li, S.; Ye, L.; Zhao, W.; Zhang, S.; Mukherjee, S.; Ade, H.; Hou, J. Energy-Level Modulation of Small-Molecule Electron Acceptors to Achieve over 12\% Efficiency in Polymer Solar Cells. Adv. Mater. 2016, 28, 9423-9429. [CrossRef] [PubMed]

4. Zhao, W.; Qian, D.; Zhang, S.; Li, S.; Inganas, O.; Gao, F.; Hou, J. Fullerene-Free Polymer Solar Cells with over 11\% Efficiency and Excellent Thermal Stability. Adv. Mater. 2016, 28, 4734-4739. [CrossRef] [PubMed]

5. Wang, Z.; Li, Z.; Xu, X.; Li, Y.; Li, K.; Peng, Q. Polymer Solar Cells Exceeding 10\% Efficiency Enabled via a Facile Star-Shaped Molecular Cathode Interlayer with Variable Counterions. Adv. Funct. Mater. 2016, 26, 4643-4652. [CrossRef]

6. Zhao, W.; Li, S.; Yao, H.; Zhang, S.; Zhang, Y.; Yang, B.; Hou, J. Molecular Optimization Enables over 13\% Efficiency in Organic Solar Cells. J. Am. Chem. Soc. 2017, 139, 7148-7151. [CrossRef] [PubMed]

7. Gu, C.; Chen, Y.; Zhang, Z.; Xue, S.; Sun, S.; Zhang, K.; Zhong, C.; Zhang, H.; Pan, Y.; Lv, Y.; et al. Electrochemical route to fabricate film-like conjugated microporous polymers and application for organic electronics. Adv. Mater. 2013, 25, 3443-3448. [CrossRef] [PubMed]

8. Yuan, L.; Zhao, Y.; Zhang, J.; Zhang, Y.; Zhu, L.; Lu, K.; Yan, W.; Wei, Z. Oligomeric Donor Material for High-Efficiency Organic Solar Cells: Breaking Down a Polymer. Adv. Mater. 2015, 27, 4229-4233. [CrossRef] [PubMed]

9. Liao, H.-C.; Chen, P.-H.; Chang, R.; Su, W.-F. Morphological Control Agent in Ternary Blend Bulk Heterojunction Solar Cells. Polymers 2014, 6, 2784-2802. [CrossRef]

10. Raja, R.; Luo, S.; Hsiow, C.-Y.; Rwei, S.-P.; Wang, L. Novel Two-Dimensional Conjugated Polymer Containing Fluorinated Bithiophene as Donor and Benzoselenodiazole as Acceptor Units with Vinyl-Terthiophene Pendants for Polymer Photovoltaic Cells. Polymers 2017, 9, 272. [CrossRef]

11. Gao, Y.; Liu, M.; Zhang, Y.; Liu, Z.; Yang, Y.; Zhao, L. Recent Development on Narrow Bandgap Conjugated Polymers for Polymer Solar Cells. Polymers 2017, 9, 39. [CrossRef]

12. Kim, Y.; Lim, E. Development of Polymer Acceptors for Organic Photovoltaic Cells. Polymers 2014, 6, $382-407$. [CrossRef]

13. Liu, W.; Liang, T.; Chen, Q.; Yu, Z.; Zhang, Y.; Liu, Y.; Fu, W.; Tang, F.; Chen, L.; Chen, H. Solution-Processed 8-Hydroquinolatolithium as Effective Cathode Interlayer for High-Performance Polymer Solar Cells. ACS Appl. Mater. Interfaces 2016, 8, 9254-9261. [CrossRef] [PubMed]

14. Wu, Y.; Zhang, W.; Li, X.; Min, C.; Jiu, T.; Zhu, Y.; Dai, N.; Fang, J. Solution-processed hybrid cathode interlayer for inverted organic solar cells. ACS Appl. Mater. Interfaces 2013, 5, 10428-10432. [CrossRef] [PubMed]

15. Chen, L.-M.; Xu, Z.; Hong, Z.; Yang, Y. Interface investigation and engineering-Achieving high performance polymer photovoltaic devices. J. Mater. Chem. 2010, 20, 2575-2598. [CrossRef]

16. Zeng, H.; Zhu, X.; Liang, Y.; Guo, X. Interfacial Layer Engineering for Performance Enhancement in Polymer Solar Cells. Polymers 2015, 7, 333-372. [CrossRef]

17. Brabec, C.J.; Shaheen, S.E.; Winder, C.; Sariciftci, N.S.; Denk, P. Effect of LiF/metal electrodes on the performance of plastic solar cells. Appl. Phys. Lett. 2002, 80, 1288-1290. [CrossRef]

18. Huang, F.; Wu, H.; Wang, D.; Yang, W.; Cao, Y. Novel Electroluminescent Conjugated Polyelectrolytes Based on Polyfluorene. Chem. Mater. 2004, 16, 708-716. [CrossRef]

19. Na, S.-I.; Oh, S.-H.; Kim, S.-S.; Kim, D.-Y. Efficient organic solar cells with polyfluorene derivatives as a cathode interfacial layer. Org. Electron. 2009, 10, 496-500. [CrossRef]

20. Yan, L.; Song, Y.; Zhou, Y.; Song, B.; Li, Y. Effect of PEI cathode interlayer on work function and interface resistance of ITO electrode in the inverted polymer solar cells. Org. Electron. 2015, 17, 94-101. [CrossRef]

21. Udum, Y.; Denk, P.; Adam, G.; Apaydin, D.H.; Nevosad, A.; Teichert, C.; White, M.S.; Sariciftci, N.S.; Scharber, M.C. Inverted bulk-heterojunction solar cell with cross-linked hole-blocking layer. Org. Electron. 2014, 15, 997-1001. [CrossRef] [PubMed] 
22. Chen, H.C.; Lin, S.W.; Jiang, J.M.; Su, Y.W.; Wei, K.H. Solution-processed zinc oxide/polyethylenimine nanocomposites as tunable electron transport layers for highly efficient bulk heterojunction polymer solar cells. ACS Appl. Mater. Interfaces 2015, 7, 6273-6281. [CrossRef] [PubMed]

23. Lin, Z.; Chang, J.; Zhang, J.; Jiang, C.; Wu, J.; Zhu, C. A work-function tunable polyelectrolyte complex (PEI:PSS) as a cathode interfacial layer for inverted organic solar cells. J. Mater. Chem. A 2014, 2, 7788-7794. [CrossRef]

24. Zhou, Y.; Fuentes-Hernandez, C.; Shim, J.W.; Khan, T.M.; Kippelen, B. High performance polymeric charge recombination layer for organic tandem solar cells. Energy Environ. Sci. 2012, 5, 9827-9832. [CrossRef]

25. Li, P.; Wang, G.; Cai, L.; Ding, B.; Zhou, D.; Hu, Y.; Zhang, Y.; Xiang, J.; Wan, K.; Chen, L.; et al. High-efficiency inverted polymer solar cells controlled by the thickness of polyethylenimine ethoxylated (PEIE) interfacial layers. Phys. Chem. Chem. Phys. 2014, 16, 23792-23799. [CrossRef] [PubMed]

26. Ai, L.; Ouyang, X.; Liu, Z.; Peng, R.; Jiang, W.; Li, W.; Zhang, L.; Hong, L.; Lei, T.; Guan, Q.; et al. Highly efficient polymer solar cells using a nonconjugated small-molecule zwitterion with enhancement of electron transfer and collection. J. Mater. Chem. A 2016, 4, 14944-14948. [CrossRef]

27. Han, J.; Chen, Y.; Chen, W.; Yu, C.; Song, X.; Li, F.; Wang, Y. High Performance Small-Molecule Cathode Interlayer Materials with D-A-D Conjugated Central Skeletons and Side Flexible Alcohol/Water-Soluble Groups for Polymer Solar Cells. ACS Appl. Mater. Interfaces 2016, 8, 32823-32832. [CrossRef] [PubMed]

28. Kyaw, A.K.; Wang, D.H.; Gupta, V.; Zhang, J.; Chand, S.; Bazan, G.C.; Heeger, A.J. Efficient solution-processed small-molecule solar cells with inverted structure. Adv. Mater. 2013, 25, 2397-2402. [CrossRef] [PubMed]

29. He, Z.; Wu, H.; Cao, Y. Recent advances in polymer solar cells: Realization of high device performance by incorporating water/alcohol-soluble conjugated polymers as electrode buffer layer. Adv. Mater. 2014, 26, 1006-1024. [CrossRef] [PubMed]

30. Liu, J.; Wu, J.; Shao, S.; Deng, Y.; Meng, B.; Xie, Z.; Geng, Y.; Wang, L.; Zhang, F. Printable highly conductive conjugated polymer sensitized $\mathrm{ZnO}$ NCs as cathode interfacial layer for efficient polymer solar cells. ACS Appl. Mater. Interfaces 2014, 6, 8237-8245. [CrossRef] [PubMed]

31. White, M.S.; Olson, D.C.; Shaheen, S.E.; Kopidakis, N.; Ginley, D.S. Inverted bulk-heterojunction organic photovoltaic device using a solution-derived $\mathrm{ZnO}$ underlayer. Appl. Phys. Lett. 2006, 89, 143517. [CrossRef]

32. Zhao, Y.H.; Zhang, K.C.; Wang, Z.W.; Huang, P.; Zhu, K.; Li, Z.D.; Li, D.H.; Yuan, L.G.; Zhou, Y.; Song, B. Comprehensive Study of Sol-Gel versus Hydrolysis-Condensation Methods To Prepare ZnO Films: Electron Transport Layers in Perovskite Solar Cells. ACS Appl. Mater. Interfaces 2017, 9, 26234-26241. [CrossRef] [PubMed]

33. Lan, J.-L.; Liang, Z.; Yang, Y.-H.; Ohuchi, F.S.; Jenekhe, S.A.; Cao, G. The effect of $\mathrm{SrTiO}_{3}$ :ZnO as cathodic buffer layer for inverted polymer solar cells. Nano Energy 2014, 4, 140-149. [CrossRef]

34. Cheng, Y.-J.; Cao, F.-Y.; Lin, W.-C.; Chen, C.-H.; Hsieh, C.-H. Self-Assembled and Cross-Linked Fullerene Interlayer on Titanium Oxide for Highly Efficient Inverted Polymer Solar Cells. Chem. Mater. 2011, 23, 1512-1518. [CrossRef]

35. Saehana, S.; Muslimin; Abdullah, M. Electrochemical impedance spectroscopy study of $\mathrm{TiO}_{2}$ based solar cells. J. Renew. Sustain. Energy 2014, 6, 023109. [CrossRef]

36. Yan, Y.; Cai, F.; Yang, L.; Li, J.; Zhang, Y.; Qin, F.; Xiong, C.; Zhou, Y.; Lidzey, D.G.; Wang, T. Light-Soaking-Free Inverted Polymer Solar Cells with an Efficiency of $10.5 \%$ by Compositional and Surface Modifications to a Low-Temperature-Processed $\mathrm{TiO}_{2}$ Electron-Transport Layer. Adv. Mater. 2017, 29, 1604044. [CrossRef] [PubMed]

37. Bao, X.; Sun, L.; Shen, W.; Yang, C.; Chen, W.; Yang, R. Facile preparation of $\mathrm{TiO}_{X}$ film as an interface material for efficient inverted polymer solar cells. J. Mater. Chem. A 2014, 2, 1732-1737. [CrossRef]

38. Jiang, X.; Xu, H.; Yang, L.; Shi, M.; Wang, M.; Chen, H. Effect of CsF interlayer on the performance of polymer bulk heterojunction solar cells. Sol. Energy Mater. Sol. Cells 2009, 93, 650-653. [CrossRef]

39. Chen, F.-C.; Wu, J.-L.; Yang, S.S.; Hsieh, K.-H.; Chen, W.-C. Cesium carbonate as a functional interlayer for polymer photovoltaic devices. J. Appl. Phys. 2008, 103, 103721. [CrossRef]

40. Gupta, V.; Kyaw, A.K.; Wang, D.H.; Chand, S.; Bazan, G.C.; Heeger, A.J. Barium: An efficient cathode layer for bulk-heterojunction solar cells. Sci. Rep. 2013, 3, 1965. [CrossRef] [PubMed]

41. Zhang, Z.; Jin, Z.; Fu, W.; Shi, M.; Chen, H. Phosphate ester side-chain-modified conjugated polymer for hybrid solar cells. J. Appl. Polym. Sci. 2017, 134, 45003. [CrossRef] 
42. Shao, S.; Zheng, K.; Pullerits, T.; Zhang, F. Enhanced performance of inverted polymer solar cells by using poly(ethylene oxide)-modified $\mathrm{ZnO}$ as an electron transport layer. ACS Appl. Mater. Interfaces 2013, 5, 380-385. [CrossRef] [PubMed]

43. Zhang, F.; Ceder, M.; Inganäs, O. Enhancing the Photovoltage of Polymer Solar Cells by Using a Modified Cathode. Adv. Mater. 2007, 19, 1835-1838. [CrossRef]

44. Guan, X.; Zhang, K.; Huang, F.; Bazan, G.C.; Cao, Y. Amino N-Oxide Functionalized Conjugated Polymers and their Amino-Functionalized Precursors: New Cathode Interlayers for High-Performance Optoelectronic Devices. Adv. Funct. Mater. 2012, 22, 2846-2854. [CrossRef]

45. Wang, J.; Lin, K.; Zhang, K.; Jiang, X.-F.; Mahmood, K.; Ying, L.; Huang, F.; Cao, Y. Crosslinkable Amino-Functionalized Conjugated Polymer as Cathode Interlayer for Efficient Inverted Polymer Solar Cells. Adv. Energy Mater. 2016, 6, 1502563. [CrossRef]

46. Zhang, W.; Song, C.; Liu, X.; Fang, J. Realizing Highly Efficient Inverted Photovoltaic Cells by Combination of Nonconjugated Small-Molecule Zwitterions with Polyethylene Glycol. ACS Appl. Mater. Interfaces 2016, 8, 18593-18599. [CrossRef] [PubMed]

47. Liu, F.; Page, Z.A.; Duzhko, V.V.; Russell, T.P.; Emrick, T. Conjugated polymeric zwitterions as efficient interlayers in organic solar cells. Adv. Mater. 2013, 25, 6868-6873. [CrossRef] [PubMed]

48. Liu, Y.; Page, Z.; Ferdous, S.; Liu, F.; Kim, P.; Emrick, T.; Russell, T. Dual Functional Zwitterionic Fullerene Interlayer for Efficient Inverted Polymer Solar Cells. Adv. Energy Mater. 2015, 5, 1500405. [CrossRef]

49. Duan, C.; Wang, L.; Zhang, K.; Guan, X.; Huang, F. Conjugated Zwitterionic Polyelectrolytes and Their Neutral Precursor as Electron Injection Layer for High-Performance Polymer Light-Emitting Diodes. Adv. Mater. 2011, 23, 1665-1669. [CrossRef] [PubMed]

50. Fang, J.; Wallikewitz, B.H.; Gao, F.; Tu, G.; Müller, C.; Pace, G.; Friend, R.H.; Huck, W.T. Conjugated zwitterionic polyelectrolyte as the charge injection layer for high-performance polymer light-emitting diodes. J. Am. Chem. Soc. 2010, 133, 683-685. [CrossRef] [PubMed]

51. Page, Z.A.; Duzhko, V.V.; Emrick, T. Conjugated thiophene-containing polymer zwitterions: Direct synthesis and thin film electronic properties. Macromolecules 2012, 46, 344-351. [CrossRef]

52. Han, D.; Letteri, R.; Chan-Seng, D.; Emrick, T.; Tu, H. Examination of zwitterionic polymers and gels subjected to mechanical constraints. Polymer 2013, 54, 2887-2894. [CrossRef]

53. Ruderer, M.A.; Müller-Buschbaum, P. Morphology of polymer-based bulk heterojunction films for organic photovoltaics. Soft Matter 2011, 7, 5482-5493. [CrossRef]

54. Hildner, R.; Köhler, A.; Müller-Buschbaum, P.; Panzer, F.; Thelakkat, M. $\pi$-Conjugated Donor Polymers: Structure Formation and Morphology in Solution, Bulk and Photovoltaic Blends. Adv. Energy Mater. 2017, 7 , 1700314. [CrossRef]

55. Ruderer, M.A.; Guo, S.; Meier, R.; Chiang, H.-Y.; Körstgens, V.; Wiedersich, J.; Perlich, J.; Roth, S.V.; Müller-Buschbaum, P. Solvent-Induced Morphology in Polymer-Based Systems for Organic Photovoltaics. Adv. Funct. Mater. 2011, 21, 3382-3391. [CrossRef]

56. Müller-Buschbaum, P. The active layer morphology of organic solar cells probed with grazing incidence scattering techniques. Adv. Mater. 2014, 26, 7692-7709. [CrossRef] [PubMed]

57. Liu, Z.; Ouyang, X.; Peng, R.; Bai, Y.; Mi, D.; Jiang, W.; Facchetti, A.; Ge, Z. Efficient polymer solar cells based on the synergy effect of a novel non-conjugated small-molecule electrolyte and polar solvent. J. Mater. Chem. A 2016, 4, 2530-2536. [CrossRef]

58. Ouyang, X.; Peng, R.; Ai, L.; Zhang, X.; Ge, Z. Efficient polymer solar cells employing a non-conjugated small-molecule electrolyte. Nat. Photonics 2015, 9, 520-524. [CrossRef]

(C) 2017 by the authors. Licensee MDPI, Basel, Switzerland. This article is an open access article distributed under the terms and conditions of the Creative Commons Attribution (CC BY) license (http://creativecommons.org/licenses/by/4.0/). 